\title{
$\mathrm{Mg}-6.7$ wt.\% 알루미늄 합금의 GMA 및 GTA 용접 특성평가
}

\author{
강태훈 ${ }^{* * * *}$ - 유지영* · 김영민 ${ }^{*}$ 황인성 ${ }^{*, * *}$ - 이승환 ${ }^{* *}$ - 김동윤 ${ }^{*, * *,}$ \\ *한국생산기술연구원 접합적층연구부문 \\ **한양대학교 융합기계공학과
}

\section{Weldability Evaluation of GMAW and GTAW for Al-6.7 wt.\% Mg Alloy}

\author{
Taehoon Kang*,**, Jiyoung Yu*, Young-Min Kim*, Insung Hwang*,**, Seung Hwan Lee**, \\ and Dong-Yoon Kim*,**,
}

\begin{abstract}
*Korean Institute of Industrial Technology, Advanced Joining \& Additive Manufacturing R\&D Department, Incheon, 21999, Korea

**Hanyang University, Department of Mechanical Convergence Engineering, Seoul, 04763, Korea
\end{abstract}

†Corresponding author: kimdy@kitech.re.kr

(Received September 9, 2021; Revised October 6, 2021; Accepted October 19, 2021)

\begin{abstract}
In this study, the arc weldability of an aluminum alloy was investigated based on its Mg content. The base materials used in the experiments were aluminum with a $\mathrm{Mg}$ content of $6.7 \mathrm{wt} . \%$ (referred as Al-6Mg) and commercial A15083-O. The weldability of two types of fusion welding methods was evaluated: gas metal arc welding (GMAW) and gas tungsten arc welding (GTAW). The tensile strength, hardness, alloy composition, and microstructure properties of the welds of two types of the aluminum alloys were compared. The tensile strength values of the GMAW and GTAW welds of Al-6Mg were $20 \%$ and $10 \%$ higher than those of Al5083-O, respectively. The weld hardness of the GMAW and GTAW welds of both aluminum alloys were similar. Al-6Mg by GMAW and GTAW were smaller than those of Al5083-O. Based on the results of analysis of the welds, the residual magnesium content was as high as $37 \%$ by GMAW and $30 \%$ by GTAW.
\end{abstract}

Key Words: 5xxx series aluminum alloy, High $\mathrm{Mg}$ weight, Gas metal arc welding, Gas tungsten arc welding, Mechanical properties, Chemical properties

\section{1. 서 론}

알루미늄의 비중은 $2.7 \mathrm{~kg} / \mathrm{m}^{3}$ 으로 강재의 비중 $7.8 \mathrm{~kg} / \mathrm{m}^{3}$ 보다 약 3 배 낮은 비중으로 강재 대비 가 볍고, 가공 및 열처리를 통해 중량 대비 높은 강도를 가진다 ${ }^{1)}$. 이러한 특성으로 인하여 알루미늄은 자동차 산업을 포함한 다양한 분야에 사용되고 있으며 ${ }^{1-7)}$, 자 동차 산업분야에서는 차체 및 샤시 등 자동차 부품에 $5000,6000,7000$ 계열의 알루미늄 합금이 적용되고 있다 ${ }^{69}$. 알루미늄 합금의 판재 및 압출재 등을 사용하 여 자동차 부품을 제작하기 위해서는 알루미늄 합금의 접합기술의 필요성이 증가하고 있다. 열 처리형 6000
계열의 $\mathrm{Al}-\mathrm{Mg}-\mathrm{Si}$ 계 알루미늄 합금은 용융용접에서 용 접에 의해 투입되는 열로 소재의 열처리가 풀려 용접부 강도가 저하되는 특징이 있고 ${ }^{10)}, 7000$ 계열의 $\mathrm{Al}-\mathrm{Zn}^{-}$ $\mathrm{Mg}$ 계 알루미늄 합금은 시효성이 우수하여 용접 열에 의해 경도가 저하된 연화부가 용접 후의 시간이 경과됨 에 따라 원래의 상태를 회복하지만 용접 균열의 감수성 이 높다는 단점이 있다 ${ }^{11)}$. 5000계열의 $\mathrm{Al}-\mathrm{Mg}$ 계 알루 미늄 합근은 다른 알루미늄 합금에 비해 내식성, 가공 성, 용접성이 우수하고, 소재 수급에 유리하여 용융용 접에 적용하여 자동차 부품을 제작하는 부위에 적용되 고 있다 ${ }^{7)}$. 5000계열 알루미늄 합금은 $\mathrm{Mg}$ 함량이 증 가할수록 기계적 특성 중 하나인 강도가 증가한다 ${ }^{12,13)}$. 하지만 용융용접시 마그네슘이 기화되고 이는 용접부의

Journal of Welding and Joining, Vol.39 No.5(2021) pp471-479

https://doi.org/10.5781/JWJ.2021.39.5.2 
강도를 저하 시킨다 ${ }^{12,13)}$. 용접부의 강도를 향상시키기 위하여 cold metal transition(CMT)와 같은 저 입 열 용융용접을 사용하여 용접부의 기계적 특성을 향상 시키거나 ${ }^{14)}$, 용접소재에 $\mathrm{Mg}$ 함량을 증가시켜 새로운 용접소재를 개발하고 있다 ${ }^{15)}$.

본 연구에서는 마그네슘 $6.7 \mathrm{wt} \%$ 를 함유한 알루 미늄 $(\mathrm{Al}-6 \mathrm{Mg})$ 판재가 개발되었고, $\mathrm{Al}-6 \mathrm{Mg}$ 합금의 GMAW와 GTAW 특성을 분석하기 위하여 $\mathrm{Al} 5083-\mathrm{O}$ 합금과의 비교 실험을 수행하였다. GMAW 및 GTAW 의 적정 용접구간을 선정하였고, 용접 특성(기계적 특 성, 화학적 특성)을 비교 분석하였다. 마그네슘이 6.7 wt.\% 함유된 $\mathrm{Al}-6 \mathrm{Mg}$ 의 용접부 인장강도가 $\mathrm{Al} 5083^{-}$ $\mathrm{O}$ 의 용접부보다 GMAW에서 최대 $20 \%, \mathrm{GTAW}$ 에서 최대 $10 \%$ 높았다. $\mathrm{Al}-6 \mathrm{Mg}$ 의 용접부 인장강도가 향상 된 원인을 확인하기 위하여 전자주사현미경(scanning electron microscope, SEM)의 energy dispersive X-ray spectrometer(EDS)모드를 사용하여 용접부 잔여 마그네슘 함량을 분석하였으며, 분석결과 $\mathrm{Al}-6 \mathrm{Mg}$ 의 잔여 마그네슘 함량이 $\mathrm{GMAW}$ 의 경우 $37 \%$, $\mathrm{GTAW}$ 의 경우 $30 \%$ 정도 높았다. 그리고 회절패턴 분 석기(electron back scatter diffraction, EBSD)를 통해 용접부 결정립 크기를 측정하였으며, $\mathrm{Al}-6 \mathrm{Mg}$ 의 $\mathrm{GMAW}$ 및 GTAW의 용접부 평균 결정립 크기가 모두 $15 \%$ 정도 낮았다. 이러한 이유로 $\mathrm{Al}-6 \mathrm{Mg}$ 가 $\mathrm{Al} 5083-\mathrm{O}$ 의 용접부보다 높은 인장강도를 보이는 것으로 판단된다.

\section{2. 실험 방법}

\section{1 용접 소재}

Table 1에 Al- $6 \mathrm{Mg}$ 합금과 $\mathrm{Al} 5083-\mathrm{O}$ 합금의 화학
적 조성을 나타내었다. 본 연구에서는 마그네슘을 6.7 wt.\% 함유한 두께 $1.5 \mathrm{~mm}$ 의 $\mathrm{Al}-6 \mathrm{Mg}$ 판재와 마그 네슘을 $4.57 \mathrm{wt} \%$ 함유한 두께 $1.5 \mathrm{~mm}$ 의 Al5083$\mathrm{O}$ 판재가 사용되었다. Table 2 와 같이 $\mathrm{Al}-6 \mathrm{Mg}$ 의 모 재 인장강도는 $452 \mathrm{MPa}$ 로 $\mathrm{Al} 5083-\mathrm{O}$ 의 모재 인장강 도 $305 \mathrm{MPa}$ 대비 약 $33 \%$ 높은 강도를 가진다. 모재 경도의 경우, $\mathrm{Al}-6 \mathrm{Mg}$ 가 $137 \mathrm{HV}, \mathrm{Al} 5083-\mathrm{O}$ 의 모재 경도는 $92 \mathrm{HV}$ 로 $\mathrm{Al}-6 \mathrm{Mg}$ 의 모재 경도값이 $33 \%$ 높 은 값을 보인다.

\section{2 용접 공정별 용접 조건}

\subsubsection{GMAW 조건}

GMAW의 와이어로는 직경 $1.2 \mathrm{~mm}$ 의 $\mathrm{AWS}$ A5 $1.0 \mathrm{ER} 5356$ 을 사용하였고, 용접 와이어의 화학적 조 성은 Table 3에 나타내었다. GMAW 실험의 모식도 는 Fig. 1 과 같다. $150 \mathrm{~mm} \times 150 \mathrm{~mm}$ 두 개의 시 험편을 맞대기 이음부로 $130 \mathrm{~mm}$ 용접을 수행하였다. Table 4에서는 GMAW 조건을 보여준다. GMAW의 경우 용접전원으로는 TPS5000(Fronius international, Austria), 전류타입은 DCEP(direct current electrode positive) 극성의 DC(direct current) pulse가 사용되었다. 사용된 용접전원은 일원제어로 와이어 송급속도 변수에 따라 적정 전압을 선정해 주는 특성을 가지고 있다. 와이어 송급속도는 $2.5-4.0$ $\mathrm{m} / \mathrm{min}$ 총 4 수준으로 실험을 수행하였다. 4 수준의 와이어 송급속도 조건에서의 전압은 $15-17 \mathrm{~V}$ 수준 이었다. 용접속도는 $60 \mathrm{~cm} / \mathrm{min}$ 으로 고정하였고, 모재 와 팁의 거리는 $15 \mathrm{~mm}$, 전진 각은 $10^{\circ}$, 차폐가스로 는 $100 \%$ 알곤을 유량 $15 \mathrm{~L} / \mathrm{min}$ 의 조건으로 실험을 수행하였다.

Table 1 Chemical compositions of base metal (wt.\%)

\begin{tabular}{|c|c|c|c|c|c|c|c|c|c|}
\hline & $\mathrm{Si}$ & $\mathrm{Fe}$ & $\mathrm{Cu}$ & $\mathrm{Mn}$ & $\mathrm{Mg}$ & $\mathrm{Cr}$ & $\mathrm{Zn}$ & $\mathrm{Ti}$ & $\mathrm{Al}$ \\
\hline $\mathrm{Al}-6 \mathrm{Mg}$ & 0.084 & 0.17 & 0.002 & 0.009 & 6.7 & $<0.001$ & 0.013 & 0.004 & Bal. \\
\hline $\mathrm{Al} 5083-\mathrm{O}$ & 0.40 & 0.40 & 0.10 & $0.40-1.0$ & 4.57 & $0.05-0.25$ & 0.25 & 0.15 & Bal. \\
\hline
\end{tabular}

Table 2 Mechanical properties of base metal

\begin{tabular}{|c|c|c|c|c|}
\hline & Yield strength $(\mathrm{MPa})$ & Tensile strength $(\mathrm{MPa})$ & Hardenss $(\mathrm{HV})$ & Elongation $(\%)$ \\
\hline Al-6Mg & 389 & 452 & 137 & 9.0 \\
\hline A15083-O & 151 & 305 & 92 & 23.7 \\
\hline
\end{tabular}

Table 3 Chemical compositions of GMAW filler wire (wt.\%)

\begin{tabular}{|c|c|c|c|c|c|c|c|c|c|}
\hline & $\mathrm{Si}$ & $\mathrm{Fe}$ & $\mathrm{Cu}$ & $\mathrm{Mn}$ & $\mathrm{Mg}$ & $\mathrm{Cr}$ & $\mathrm{Zn}$ & $\mathrm{Ti}$ & $\mathrm{Al}$ \\
\hline AWS A5.10 ER5356 & 0.10 & 0.17 & 0.03 & 0.08 & 4.80 & 0.08 & 0.01 & 0.07 & Bal. \\
\hline
\end{tabular}




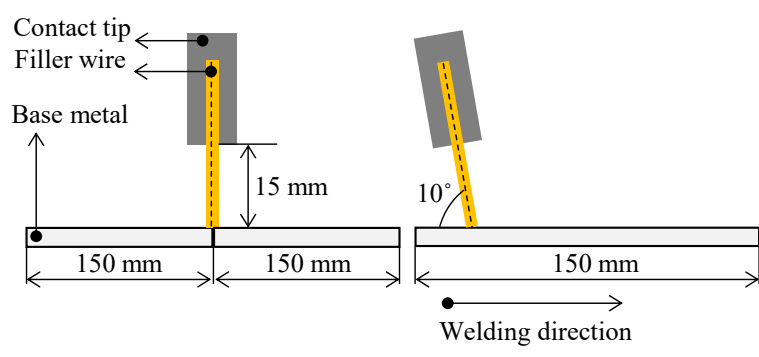

Fig. 1 Schematic diagram of GMAW

Table 4 GMAW conditions

\begin{tabular}{|c|c|}
\hline Welding type & Butt welding \\
\hline Conditions & Fronius Trans Pulse Synergic 5000 \\
\hline Current type & DC pulse (Polarity: DCEP) \\
\hline Wire feed rate & $2.5-4.0 \mathrm{~m} / \mathrm{min}(4$ levels $)$ \\
\hline Current & $60-90 \mathrm{~A}$ \\
\hline Voltage & $15-17 \mathrm{~V}$ \\
\hline Welding speed & $60 \mathrm{~cm} / \mathrm{min}$ \\
\hline CTWD & $15 \mathrm{~mm}$ \\
\hline Travel angle & Push $10^{\circ}$ \\
\hline Shielding gas & Ar $100 \%(15 \mathrm{~L} / \mathrm{min})$ \\
\hline
\end{tabular}

\subsubsection{GTAW 조건}

GTAW의 전극봉은 직경 $1.6 \mathrm{~mm}$ 의 Binzel사의 E3 전극봉을 $60^{\circ}$ 가공하여 사용하였고, 전극봉의 화학적 조성은 Table 5에 나타냈다. GTA 용접실험의 모식도 는 Fig. 2 와 같다. $150 \mathrm{~mm} \times 150 \mathrm{~mm}$ 두 개의 시험편 맞대기 이음부 $130 \mathrm{~mm}$ 용접을 수행하였다. Table 6 에서는 GTAW의 용접 조건을 나타내었다. GTAW의 경우 용접전원으로는 Lorch V30 (Lorch, Germany) 을 전류타입은 DCEN (direct current electrode negative) 극성의 $\mathrm{DC}$ 를 사용하였다. 용접전류는 60 - $90 \mathrm{~A}$ 총 4 수준으로 실험을 수행하였다. 4 수준의

Table 5 Chemical compositions of GTAW Tungsten electrode (wt.\%)

\begin{tabular}{|c|c|c|c|c|}
\hline & La & Zr & Y & W \\
\hline E3 & 1.5 & 0.08 & 0.08 & Bal. \\
\hline
\end{tabular}

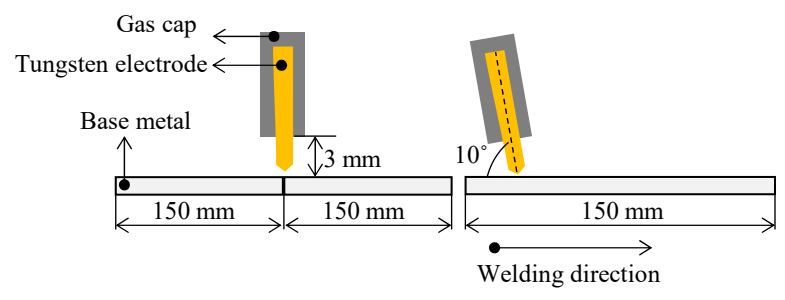

Fig. 2 Schematic diagram of GTAW
Table 6 GTAW conditions

\begin{tabular}{|c|c|}
\hline Welding type & Butt welding \\
\hline Conditions & Lorch V30 \\
\hline Power source & Direct current (Polarity: DCEN) \\
\hline Current type & $60-90 \mathrm{~A}(4$ levels $)$ \\
\hline Current & $12-14 \mathrm{~V}$ \\
\hline Voltage & $80 \mathrm{~cm} / \mathrm{min}$ \\
\hline Welding speed & $3 \mathrm{~mm}$ \\
\hline CTWD & Push $10^{\circ}$ \\
\hline Travel angle & Ar $100 \%(15 \mathrm{~L} / \mathrm{min})$ \\
\hline Shielding gas &
\end{tabular}

용접전류 조건에서 전압은 $12-14 \mathrm{~V}$ 수준이었다. 용 접속도는 $80 \mathrm{~cm} / \mathrm{min}$ 으로 고정하였고, 모재와 전극봉 사이의 거리는 $3 \mathrm{~mm}$, 전진 각은 $10^{\circ}$, 차폐가스로는 $100 \%$ 알곤을 유랑 $15 \mathrm{~L} / \mathrm{min}$ 의 조건으로 실험을 수 행하였다.

\section{3 용접부 기계적 특성 평가 방법}

인장강도 시험편의 KS B0801 규격에 의거하여 제 작하였으며, 인장시험편의 형상은 Fig. 3과 같다. 인장 시험에서 용접부 형상의 영향을 최소화하기 위하여, GMAW, GTAW의 인장시편 모두 모재 상면을 기준 깊이방향 $0.3 \mathrm{~mm}$, 모재의 하면을 기준 깊이방향 0.1 $\mathrm{mm}$ 로 밀링 가공을 통해 제작 되었다. 밀링 가공의 위 치는 Fig. 4 에 나타내었다. 동일 조건 총 3 개의 인장 시험편을 가공하였고, 용접부 인장 시험 속도는 5.0 $\mathrm{mm} / \mathrm{min}$ 으로 수행하였다. 3 개의 시편에 대한 인장시

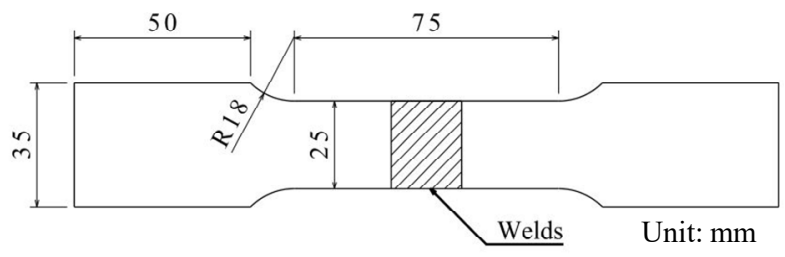

Fig. 3 Weld tensile test specimen schematic

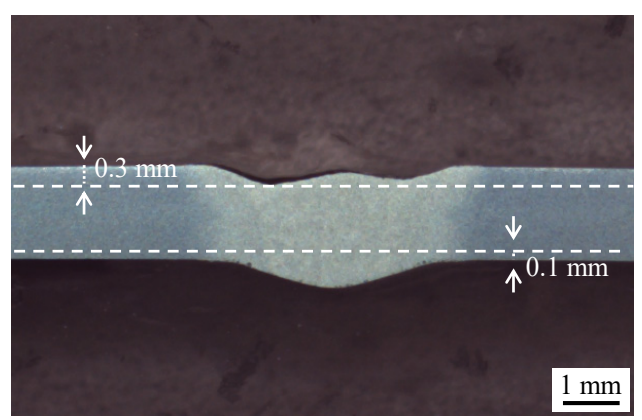

Fig. 4 Milling method for tensile test of welds 


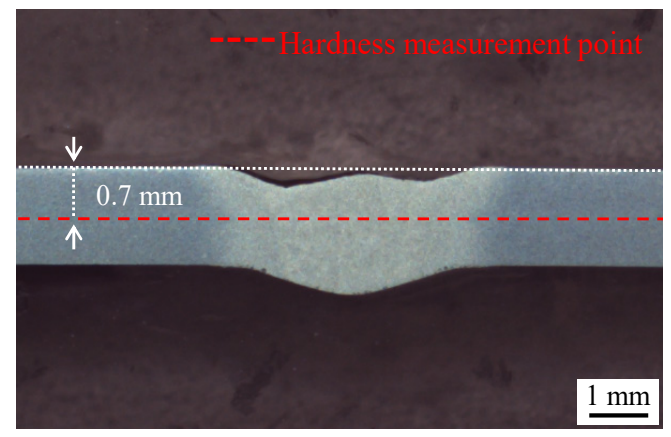

Fig. 5 Hardness measurement point

험을 실시한 후 평균값을 용접부 인장강도로 선정하였다.

Fig. 5는 용접부의 경도측정 위치를 보여준다. 용접 부 경도측정을 위하여 경도 측정기 비커스 경도기 $(\mathrm{HM}-$ $200)$ 를 활용하여 모재 상면기준 깊이방향 $0.7 \mathrm{~mm}$ 위 치에서 GMAW, GTAW 모두 총 $30 \mathrm{~mm}$ 의 길이를 $0.2 \mathrm{~mm}$ 간격으로 총 151타점, $\mathrm{HV} 0.2$ 로 측정하였다.

\section{4 용접부 화학적 및 미세조직 특성 평가}

용접부 화학적 분석을 위하여 시험편을 연마하였고, 에칭액으로는 증류수 $100 \mathrm{~m} \ell$ 에 Sodium hydroxide $20 \mathrm{~g}$ 을 첨가한 수산화나트륨 수용액을 사용하였다. Fig. 6(a)는 용접부의 잔여 마그네슘 함량을 측정하기 위한 $\mathrm{EDS}$ 측정 위치를 나타낸다. 용접부의 잔여 마그 네슘 함량을 확인하기 위하여 상판 기준 깊이방향으로 $0.3 \mathrm{~mm}$ (top), $0.7 \mathrm{~mm}$ (middle), $1.3 \mathrm{~mm}$ (bottom) 위치에서 잔여 마그네슘 함량을 측정하였고, top, middle, bottom 부위의 측정값의 평균 마그네슘 함량을 구하여 비교 분석을 진행하였다. 또한, Fig. 6(b)와 같이 시험편의 용접부(1)와 용접부 및 열영향부(2)에 대하여 $\mathrm{EBSD}$ 분석을 통해 미세 결정립의 이미지를 얻 었고, 결정립 이미지를 $\mathrm{OIM}$ 분석하여 공정별 각 소재 용접부의 평균 결정립 크기를 비교하였다.

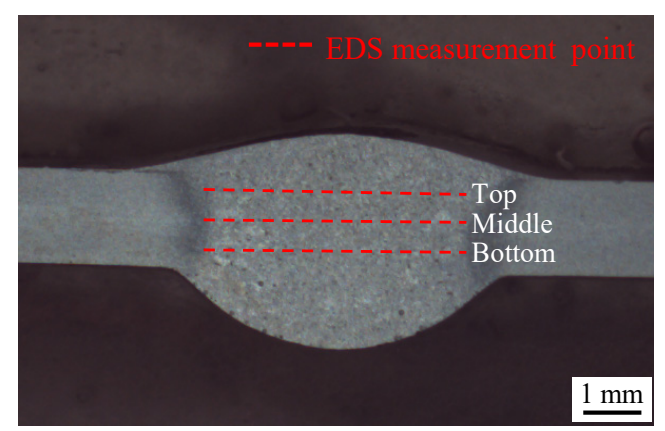

(a)

\section{3. 실험 결과}

\section{1 용접 최적구간 선정}

최적 용접 조건을 선정하기 위해 GMAW, GTAW 모두 4 수준의 용접조건으로 실험을 진행하였다. Fig. 7은 GMAW의 와이어 송급 속도(wire feed rate, $\mathrm{WFR}$ )에 따른 용접 조건(전류, 전압)과 각 조건에서의 용접부 외관, 단면, 그리고 입열량을 보여준다. 와이어 송급 속도를 $2.5 \mathrm{~m} / \mathrm{min}$ 에서는 용착부족 현상이 발 생하고, 와이어 송급 속도를 $4.0 \mathrm{~m} / \mathrm{min}$ 으로 설정 하 였을 때는 용락이 발생하였다. 와이어 송급 속도를 $3.0,3.5 \mathrm{~m} / \mathrm{min}$ 으로 설정하였을 때는 완전용입을 확인하였다. 와이어 송급 속도가 $3.0 \mathrm{~m} / \mathrm{min}$ 일 때 용 접전류 및 용접전압은 각각 $72 \mathrm{~A}, 16.3 \mathrm{~V}$ 이었으며, 이때의 입열량은 $1,152 \mathrm{~J} / \mathrm{cm}$ 이었다. 와이어 송급 속 도가 $3.5 \mathrm{~m} / \mathrm{min}$ 일 때 용접전류 및 용접전압은 각각 $83 \mathrm{~A}, 16.1 \mathrm{~V}$ 이었으며 이때의 입열량은 $1,328 \mathrm{~J} / \mathrm{cm}$ 이었다. 이와 같은 결과를 바탕으로 $\mathrm{GMAW}$ 의 최적구 간은 와이어 송급 속도 $3.0,3.5 \mathrm{~m} / \mathrm{min}$ 두 가지 구 간으로 선정하였다. 또한 $\mathrm{Al}-6 \mathrm{Mg}, \mathrm{Al} 5083-\mathrm{O}$ 판재모 두 동일 와이어 송급속도에서 유사한 용접부 형상을 보 였다.

Fig. 8은 GTAW의 용접전류에 따른 용접부 외관, 단면, 그리고 입열량을 보여준다. 용접전류를 $60 \mathrm{~A}$ 로 설정하였을 때는 용접부에서 결함이 발생하였고. 용접 전류를 $90 \mathrm{~A}$ 로 설정하였을 때는 용락이 발생하였다. 용접전류는 $70,80 \mathrm{~A}$ 로 설정 하였을 때는 완전용입 을 확인하였다. 용접전류가 $70 \mathrm{~A}$ 일 때, 용접 전압은 $14 \mathrm{~V}$ 이었으며, 이때의 입열량은 $751 \mathrm{~J} / \mathrm{cm}$ 이었다. 용접전류 $80 \mathrm{~A}$ 일 때, 용접 전압은 마찬가지로 $14 \mathrm{~V}$ 이었으며, 이때의 입열량은 $852 \mathrm{~J} / \mathrm{cm}$ 이었다. 이와 같은 결과를 바탕으로 $\mathrm{GTAW}$ 의 용접 최적구간은 용접 전류 $70,80 \mathrm{~A}$ 두 가지 구간으로 선정하였다. 또한

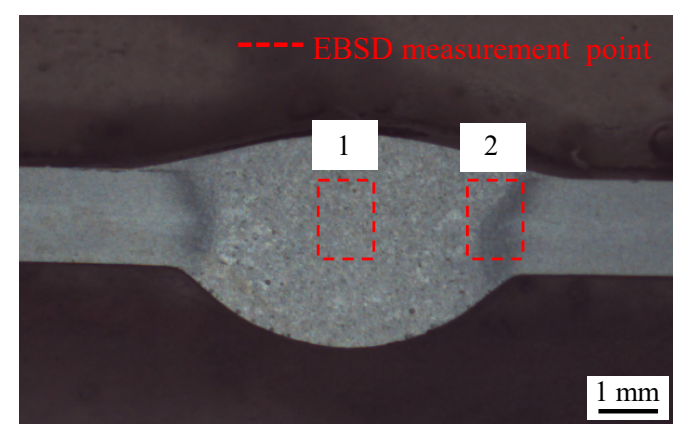

(b)

Fig. 6 (a) EDS measurment point, (b) EBSD measurment point 
$\mathrm{Al}-6 \mathrm{Mg}, \mathrm{Al} 5083-\mathrm{O}$ 판재모두 동일 용접 전류 조건에 서 유사한 용접부 형상을 보였으며, 동일한 용접 최적 구간을 보였다.

\section{2 용접부 기계적 특성 평가 결과}

\subsection{1 용접부 인장강도}

입열량에 따른 GMAW 및 GTAW의 인장시험 결과 는 Fig. 9에 나타내었다. GMAW의 용접부 인장 시험 결과 선정한 모든 입열조건에서 $\mathrm{Al}-6 \mathrm{Mg}$ 의 용접부 인 장강도가 $\mathrm{Al} 5083-\mathrm{O}$ 에 비하여 더 높은 값을 보였으며, 용접 최적구간의 입열량은 $1,100-1,400 \mathrm{~J} / \mathrm{cm}$ 수준
이었다. 입열량이 $1,152 \mathrm{~J} / \mathrm{cm}$ 조건에서 $\mathrm{Al}-6 \mathrm{Mg}$ 의 용접부 인장강도는 $258 \mathrm{MPa}, \mathrm{Al} 5083-\mathrm{O}$ 의 용접부 인장강도는 $210 \mathrm{MPa}$ 로 $\mathrm{Al}-6 \mathrm{Mg}$ 의 용접부 인장강도 가 $20 \%$ 높았다. 입열량이 $1,328 \mathrm{~J} / \mathrm{cm}$ 조건에서는 $\mathrm{Al}-6 \mathrm{Mg}$ 및 $\mathrm{Al} 5083-\mathrm{O}$ 의 용접부 인장강도는 각각 $244 \mathrm{MPa}, 205 \mathrm{MPa}$ 으로 $\mathrm{Al}-6 \mathrm{Mg}$ 의 용접부 인장강 도가 $20 \%$ 높았다. GTAW의 용접부 인장 시험결과 선정한 모든 입열조건에서 $\mathrm{Al}-6 \mathrm{Mg}$ 의 용접부 인장강도 가 $\mathrm{Al} 5083-\mathrm{O}$ 에 비하여 더 높은 값을 보였으며, 용접 최적구간의 입열량은 $700-900 \mathrm{~J} / \mathrm{cm}$ 수준이었다. 입열량이 $751 \mathrm{~J} / \mathrm{cm}$ 조건에서 $\mathrm{Al}-6 \mathrm{Mg}$ 의 용접부 인장 강도는 $280 \mathrm{MPa}, \mathrm{Al} 5083-\mathrm{O}$ 의 용접부 인장강도는

\begin{tabular}{|c|c|c|c|c|}
\hline Base metal & 2.5 & 3.0 & 3.5 & 4.0 \\
\hline $\mathrm{AlMa6}$ & Lack of fusion & $\begin{array}{ll}2 & \\
1.0 \mathrm{~mm} & 1152 \mathrm{~J} / \mathrm{cm}\end{array}$ & $\begin{array}{ll} & \\
1.0 \mathrm{~mm} & 1328 \mathrm{~J} / \mathrm{cm} \\
\end{array}$ & Burn through \\
\hline & Lack of fusion & $\overline{1.0 \mathrm{~mm}}$ & $16.1 \mathrm{~V}$ & Burn through \\
\hline \multirow{2}{*}{ Al5083-O } & Lack of fusion & 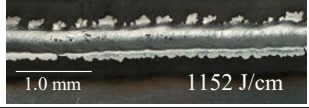 & $1328 \mathrm{~J} / \mathrm{cm}$ & Burn through \\
\hline & Lack of fusion & $\overline{1.0 \mathrm{~mm}}$ & $.2 \mathrm{~V}$ & Burn through \\
\hline
\end{tabular}

Fig. 7 Bead appearance and cross section of Al-6Mg and Al5083-O in GMAW

\begin{tabular}{|c|c|c|c|c|c|c|}
\hline $\begin{array}{l}\text { Current (A) } \\
\text { Base metal }\end{array}$ & 60 & & & & & 90 \\
\hline \multirow{3}{*}{ AlMg6 } & Lack of fusion & $x$ & 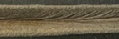 & 5 & 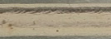 & Burn through \\
\hline & & $1.0 \mathrm{~mm}$ & $751 \mathrm{~J} / \mathrm{cm}$ & $1.0 \mathrm{~mm}$ & $852 \mathrm{~J} / \mathrm{cm}$ & \\
\hline & Lack of fusion & & & & & Burn through \\
\hline \multirow{4}{*}{ Al5083-O } & Lack of fusion & Sen & $=$ & & & Burn through \\
\hline & & $1.0 \mathrm{~mm}$ & $751 \mathrm{~J} / \mathrm{cm}$ & in & $852 \mathrm{~J} / \mathrm{cm}$ & \\
\hline & \multirow[t]{2}{*}{ Lack of fusion } & & & & & \multirow[t]{2}{*}{ Burn throug } \\
\hline & & $\overline{1.0 \mathrm{~mm}}$ & $70 \mathrm{~A} / 14 \mathrm{~V}$ & $1.0 \mathrm{~mm}$ & $80 \mathrm{~A} / 14 \mathrm{~V}$ & \\
\hline
\end{tabular}

Fig. 8 Bead appearance and cross section of Al-6Mg and Al5083-O in GTAW 


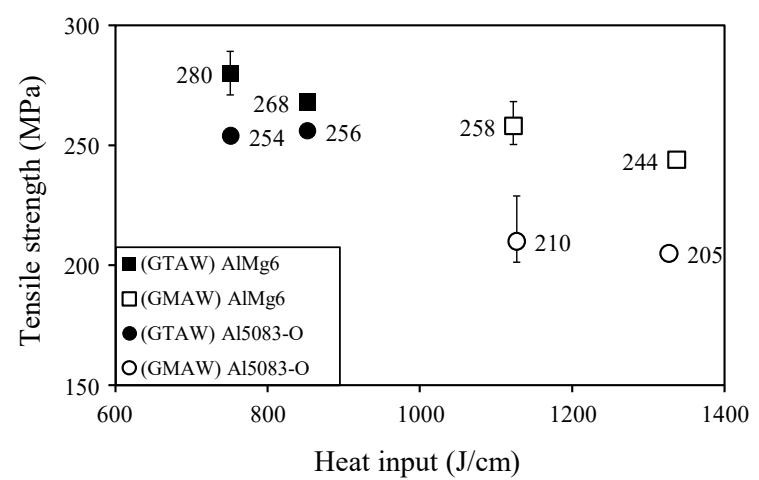

Fig. 9 Weld tensile strength to heat input of $\mathrm{Al}-6 \mathrm{Mg}$ and A15083-O

$254 \mathrm{MPa}$ 로 $\mathrm{Al}-6 \mathrm{Mg}$ 의 용접부 인장강도가 약 $10 \%$ 높았다. 입열량이 $852 \mathrm{~J} / \mathrm{cm}$ 조건에서는 $\mathrm{Al}-6 \mathrm{Mg}$ 및 $\mathrm{Al} 5083-\mathrm{O}$ 의 용접부 인장강도는 각각 $268 \mathrm{MPa}$, $256 \mathrm{MPa}$ 으로 $\mathrm{Al}-6 \mathrm{Mg}$ 의 용접부 인장강도가 약 $4 \%$ 높았다. 용접부 인장시험 결과 GMAW, GTAW 모두 용접부에서 파단이 발생하였고, 용접 최적구간에서 소 재의 마그네슘 함량이 더 높은 $\mathrm{Al}-6 \mathrm{Mg}$ 판재의 용접부 인장강도가 더 높았다. 또한 $\mathrm{Al}-\mathrm{Mg} 6$ 판재의 경우 용 접공정과 무관하게 입열량이 증가할수록 용접부 인장강 도가 감소하는 경향을 보였으며, $\mathrm{Al} 5083-\mathrm{O}$ 판재의 경 우 용접공정별 적정용접 구간에서 유사한 용접부 인장 강도를 보였다.

\section{2 .2 용접부 경도}

Fig. 10(a)에서는 $1,328 \mathrm{~J} / \mathrm{cm}$ 의 입열량을 보였던 $\mathrm{Al}-6 \mathrm{Mg}$ 와 $\mathrm{Al} 5083-\mathrm{O}$ 의 $\mathrm{GMAW}$ 의 용접부(weld metal, WM), 열영향부(heat affect zone, HAZ), 모재 (base metal, $\mathrm{BM}$ )에서의 경도 분포를 보여준다. $\mathrm{Al}-$ $6 \mathrm{Mg}$ 시험편의 용접부 평균 경도 분포는 $78 \mathrm{HV}$ 이었 고, $\mathrm{Al} 5083-\mathrm{O}$ 의 용접부 경도 분포는 $73 \mathrm{HV}$ 로 유사 한 경도 분포를 보였다. Fig. 10(b)에서는 $751 \mathrm{~J} / \mathrm{cm}$ 의 입열량을 보였던 $\mathrm{Al}-6 \mathrm{Mg}$ 와 $\mathrm{Al} 5083-\mathrm{O}$ 의 GTAW 의 용접부, 열영향부, 모재에서의 경도 분포를 보여준 다. $\mathrm{Al}-6 \mathrm{Mg}$ 와 $\mathrm{Al} 5083-\mathrm{O}$ 의 평균 용접부 경도는 각각 $88 \mathrm{HV}, 85 \mathrm{HV}$ 로 유사하였다.

$\mathrm{Al}-6 \mathrm{Mg}$ 와 $\mathrm{Al} 5083-\mathrm{O}$ 의 용접부 경도측정 결과 두 공정 모두 모재에서 $\mathrm{Al}-6 \mathrm{Mg}$ 의 경도가 높은 값을 보였 지만, GMAW 및 GTAW의 용접부에서는 모두 유사한 경도 값을 보였다.

\section{3 용접부 화학적 특성평가 결과}

\subsection{1 용접부 성분분석}

Fig. 11 에는 입열량이 $1,328 \mathrm{~J} / \mathrm{cm}$ 로 가장 높았던

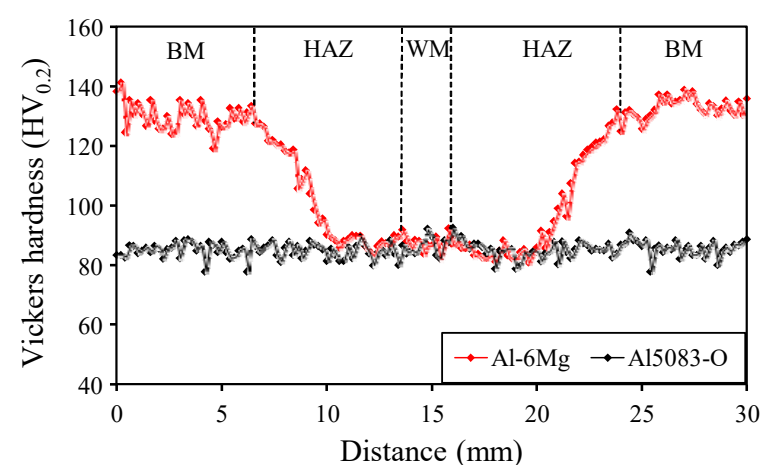

(a) GMAW

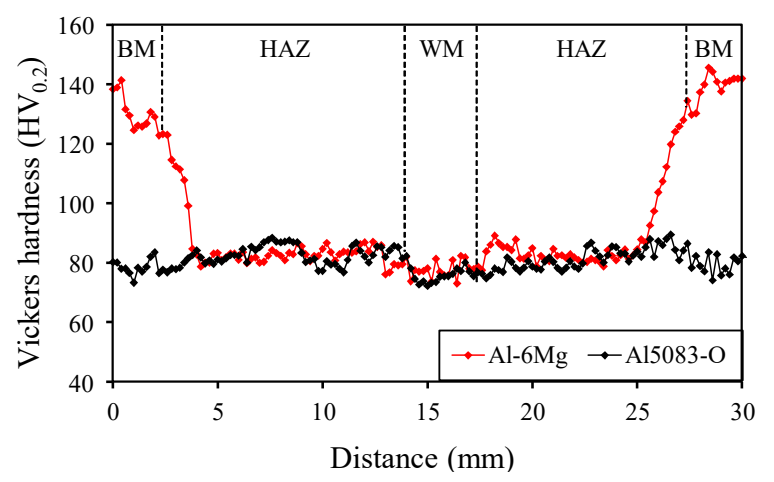

(b) GTAW

Fig. 10 Comparison the hardness of $\mathrm{Al}-6 \mathrm{Mg}$ and A15083-O

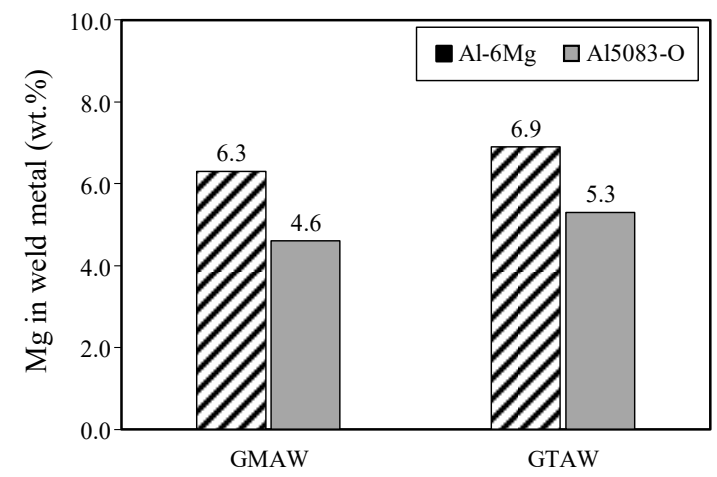

Fig. 11 Comparison of the residual $\mathrm{Mg}$ content in weld metal of Al-6Mg and Al5083-O

GMAW의 시험편 2개와, $751 \mathrm{~J} / \mathrm{cm}$ 의 입열량을 보였 던 GTAW의 용접 시험편 2개, 총 4개의 시험편에 대 하여 용접부의 잔여 마그네슘 함량을 나타내었다. $\mathrm{Al}-$ $6 \mathrm{Mg}$ 의 GMAW 용접부 top, middle, bottom의 마그 네슘 함량 측정결과 각각 $6.1,6.3,6.3$ wt.\%였고, 평균값은 $6.3 \mathrm{wt} . \%$ 로 나타났다. Al5083-O의 GMAW 용접부 top, middle, bottom의 마그네슘 함량 측정결 과 각각 4.4, 4.7, $4.7 \mathrm{wt} . \%$ 였고, 평균값은 $4.6 \mathrm{wt} . \%$ 로 나타났다. $\mathrm{Al}-6 \mathrm{Mg}$ 의 용접부 잔여 마그네슘 함량은 $\mathrm{Al} 5083-\mathrm{O}$ 에 비해 $37 \%$ 높게 나타났다. $\mathrm{Al}-6 \mathrm{Mg}$ 의 


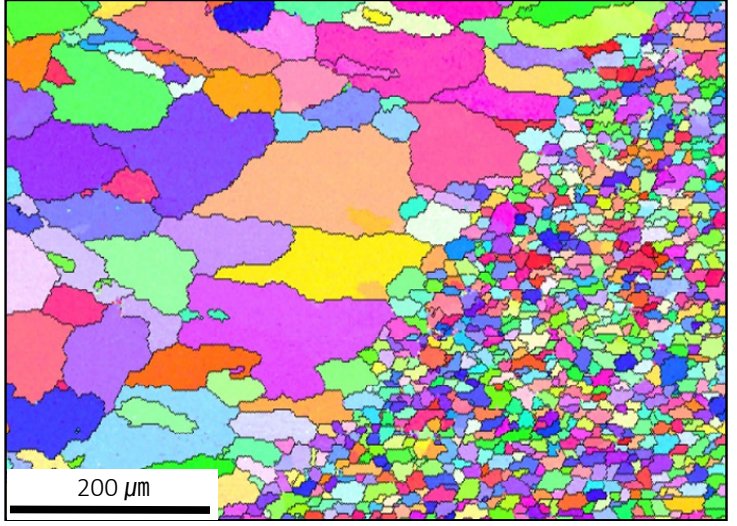

(a) WM \& HAZ of $\mathrm{Al}-6 \mathrm{Mg}$

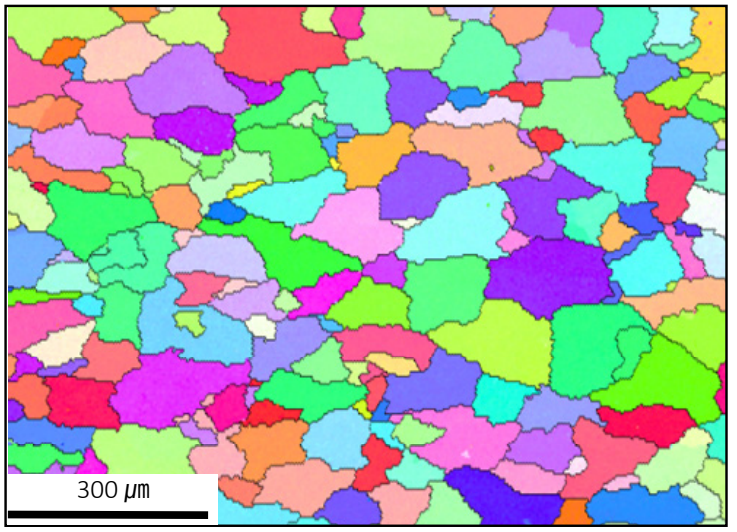

(b) $\mathrm{WM}$ of $\mathrm{Al}-6 \mathrm{Mg}$

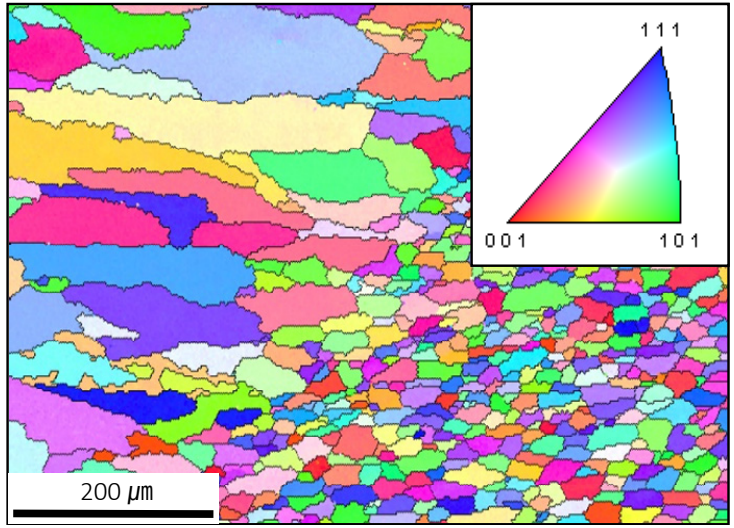

(c) WM \& HAZ of Al5083-O

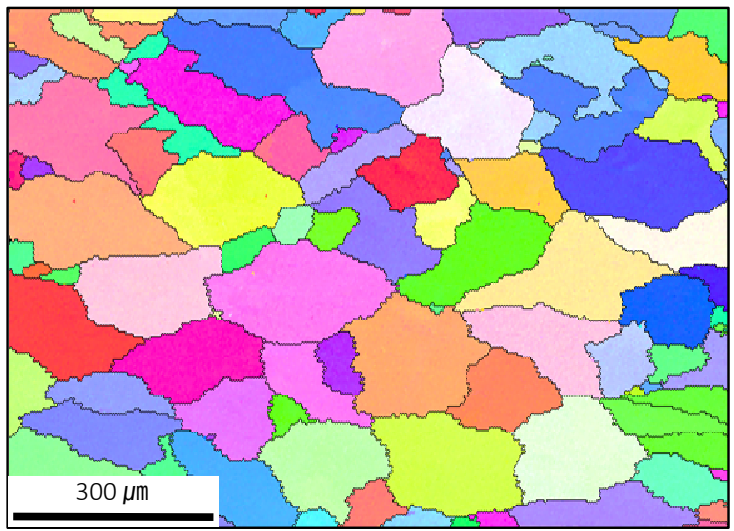

(d) $\mathrm{WM}$ of $\mathrm{Al} 5083-\mathrm{O}$

Fig. 12 GMAW welding EBSD analysis results

GTAW 용접부 top, middle, bottom의 마그네슘 함 량 측정결과 각각 $6.9,6.9,7.0 \mathrm{wt} \%$ 였고, 평균값은 6.9 wt.\%로 나타났다. Al5083-O의 GTAW 용접부 top, middle, bottom의 마그네슘 함량 측정결과 각각 $5.3,5.3,5.3 \mathrm{wt} . \%$ 였고, 평균값은 $5.3 \mathrm{wt} \%$ 로 나 타났다. $\mathrm{Al}-6 \mathrm{Mg}$ 의 용접부 잔여 마그네슘 함량이 $\mathrm{Al} 5083-\mathrm{O}$ 에 비해 $30 \%$ 높게 나타났다. 용접부 성분 분석 결과 GMAW, GTAW 두 공정에서 모두 $\mathrm{Al}-6 \mathrm{Mg}$ 의 용접부 잔여 마그네슘 함량이 $\mathrm{Al} 5083-\mathrm{O}$ 보다 높게 나타났다. 마그네슘 함량의 증가는 고용강화에 용이하 여 알루미늄 합금의 인장강도를 향상시키는 것으로 알 려져 있다 ${ }^{15)}$. 이와 같은 이유로 $\mathrm{Al}-6 \mathrm{Mg}$ 판재의 용접 부 인장강도가 $\mathrm{Al} 5083-\mathrm{O}$ 보다 높은 값을 보인 것으로 판단된다.

\subsection{2 용접부 미세조직 분석}

성분분석에 사용했던 4 개의 시편에 대한 결정립 크 기를 확인하기 위하여 용접부 및 열영향부의 $\mathrm{EBSD}$ 분 석을 수행하였다. Fig. 12에는 Al-6Mg, Al5083-O 시험편에 대한 GMAW 용접부 및 열영향부의 $\mathrm{EBSD}$ 결과를 나타낸다. $\mathrm{Al}-6 \mathrm{Mg}$ 의 용접부와 열영향부의 $\mathrm{EBSD}$
결과를 Fig. 12(a)에 용접부의 EBSD 결과를 Fig. 12(b)에 나타내었고, $\mathrm{Al} 5083-\mathrm{O}$ 의 용접부와 열영향부 의 $\mathrm{EBSD}$ 결과는 Fig $12(\mathrm{c})$ 에 용접부의 $\mathrm{EBSD}$ 결과 는 Fig. 12(d)에 나타내었다. 가장 높은 입열량을 보 였던 GMAW에서 입열량이 $1,328 \mathrm{~J} / \mathrm{cm}$ 조건일 때 $\mathrm{Al}-6 \mathrm{Mg}, \mathrm{Al} 5083-\mathrm{O}$ 두 가지 시험편에 대한 용접부 결정립 크기 분석 결과 $\mathrm{Al}-6 \mathrm{Mg}$ 의 용접부 평균 결정립 크기는 $66.1 \mu \mathrm{m}, \mathrm{Al} 5083-\mathrm{O}$ 의 평균 용접부 결정립 크 기는 $76.7 \mu \mathrm{m}$ 로 $\mathrm{Al}-6 \mathrm{Mg}$ 의 용접부 평균 결정립 크기 가 $14 \%$ 작게 나타났다.

Fig. 13 에는 Al-6Mg, Al5083-O 시험편에 대한 GTAW 용접부 및 열영향부의 EBSD 결과를 나타냈 다. $\mathrm{Al}-6 \mathrm{Mg}$ 의 용접부와 열영향부의 $\mathrm{EBSD}$ 결과를 Fig. 13(a)에 용접부의 EBSD 결과를 Fig. 13(b)에 나타내었고, $\mathrm{Al} 5083-\mathrm{O}$ 의 용접부와 열영향부의 $\mathrm{EBSD}$ 결과는 Fig 13(c)에 용접부의 EBSD 결과는 Fig. 13 (d)에 나타내었다. 가장 낮은 입열량을 보였던 GTAW 에서 입열량이 $751 \mathrm{~J} / \mathrm{cm}$ 조건일 때 $\mathrm{Al}-6 \mathrm{Mg}, \mathrm{Al} 5083-$ $\mathrm{O}$ 두 가지 시험편에 대한 용접부 결정립 크기 분석 결 과 $\mathrm{Al}-6 \mathrm{Mg}$ 의 용접부 평균 결정립 크기는 $78.4 \mu \mathrm{m}$, $\mathrm{Al} 5083-\mathrm{O}$ 의 용접부 평균 결정립 크기는 $92.8 \mu \mathrm{m}$ 로 


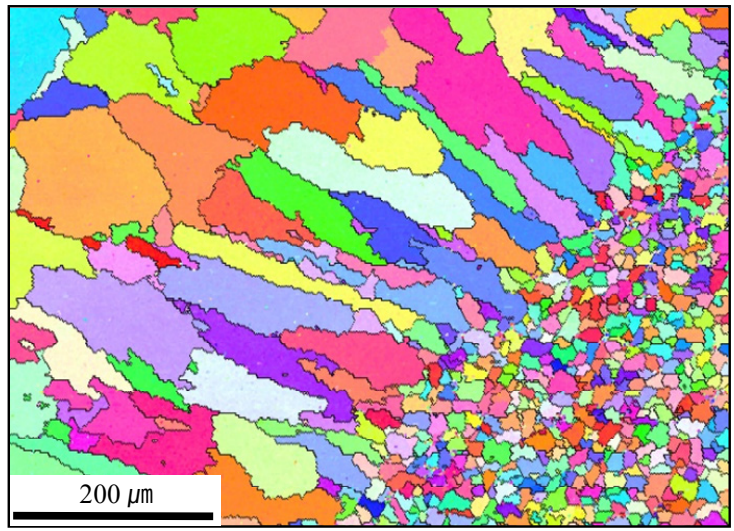

(a) $\mathrm{WM} \& \mathrm{HAZ}$ of $\mathrm{Al}-6 \mathrm{Mg}$

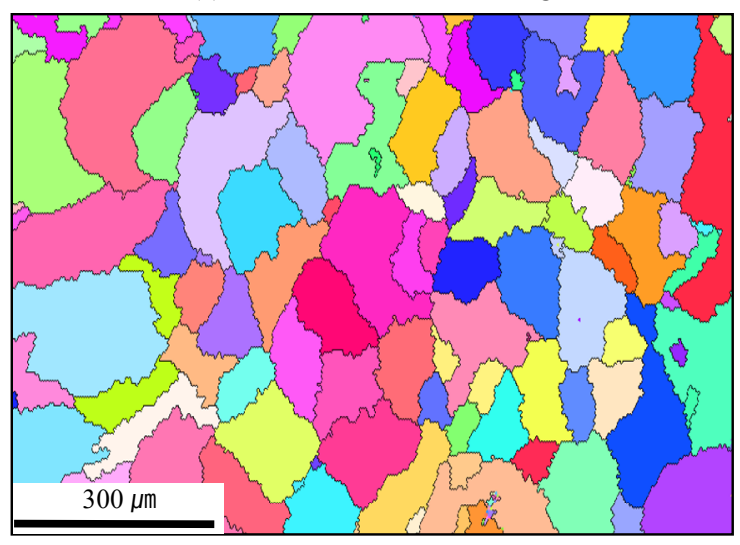

(b) $\mathrm{WM}$ of $\mathrm{Al}-6 \mathrm{Mg}$

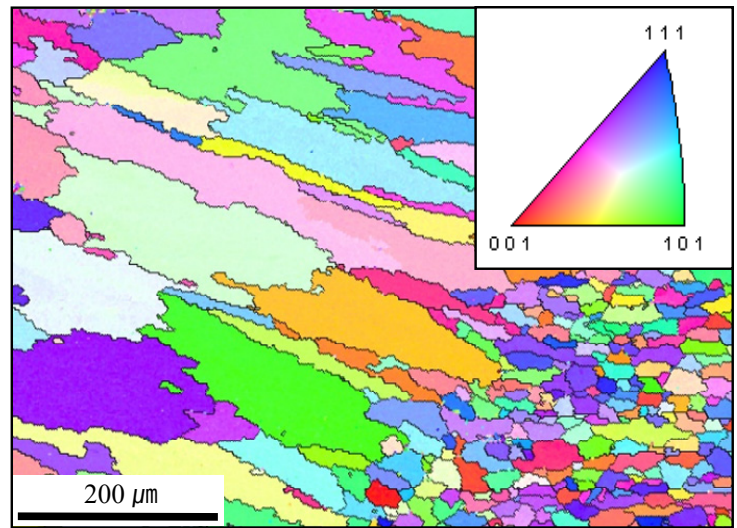

(c) WM \& HAZ of A15083-O

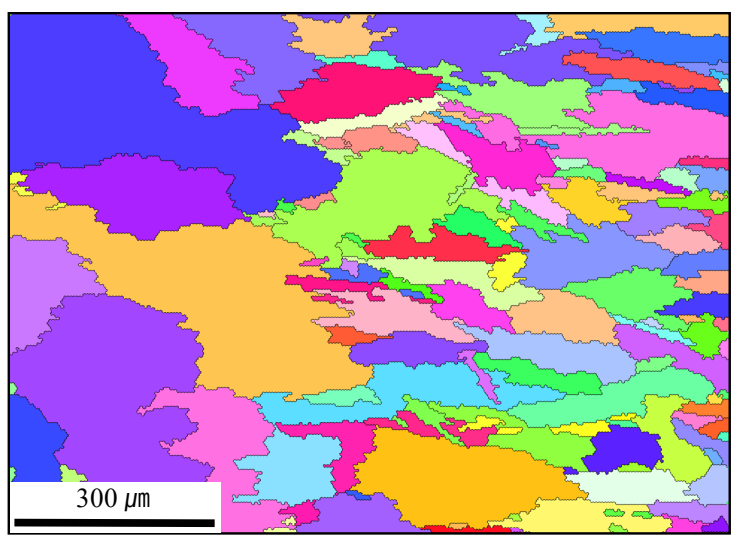

(d) WM of Al5083-O

Fig. 13 GTAW welding EBSD analysis results

$\mathrm{Al}-6 \mathrm{Mg}$ 의 용접부 평균 결정립 크기가 $16 \%$ 작게 나 타났다.

미세조직 분석 결과 GMAW, GTAW 모두 $\mathrm{Al}-6 \mathrm{Mg}$ 의 용접부 평균 결정립 크기가 $\mathrm{Al} 5083-\mathrm{O}$ 보다 작았다. 결정립의 크기가 작을 수록 결정립계의 비율이 증가하 며, 전위의 움직임에 제한이 생겨 소재의 강도는 향상하 게 된다 ${ }^{16-18)}$. 이와 같은 이유로 $\mathrm{Al}-6 \mathrm{Mg}$ 의 용접부 인 장강도가 $\mathrm{Al} 5803$ 보다 높게 나타났을 것으로 판단된다.

\section{4. 요 약}

본 연구에서는 마그네슘이 6.7 wt.\% 함유된 알루미늄 합금 $\mathrm{Al}-6 \mathrm{Mg}$ 에 대하여 기존 상용화된 알루미늄 $\mathrm{Al} 5083^{-}$ O과 GMAW, GTAW의 용접성 평가를 진행하였다.

1) GMAW 공정은 와이어 송급속도 $3.0,3.5 \mathrm{~m} / \mathrm{min}$ 에서 최적 용접 구간을 확인하였고, GTAW 공정의 경 우 용접전류 $70,80 \mathrm{~A}$ 에서 최적 용접 구간을 보였다.

2) 인장시험 결과 모든 공정 및 조건 용접부에서 파단 이 발생했으며, $\mathrm{Al}-6 \mathrm{Mg}$ 의 용접부 인장강도가 $\mathrm{Al} 5083^{-}$ $\mathrm{O}$ 대비 GMAW에서 최대 $20 \%$, GTAW에서 최대 $10 \%$ 더 높은 값을 보였다.
3) 경도시험 결과 $\mathrm{Al}-6 \mathrm{Mg}$ 의 모재 경도값이 $\mathrm{Al} 5083-$ $\mathrm{O}$ 보다 약 $33 \%$ 높았지만, 모든 공정, 조건 용접부에 서의 경도분포는 유사했다. 용접부에서의 경도분포가 유 사한 이유로는 $\mathrm{Al} 5083-\mathrm{O}$ 에 함유 된 $\mathrm{Mn}$ 과 $\mathrm{Cr}$ 의 영향 으로 판단된다.

4) 용접부 $\mathrm{EBSD}$ 분석결과 GMAW, GTAW 용접 모두 $\mathrm{Al}-6 \mathrm{Mg}$ 의 용접부 평균 결정립 크기가 약 $15 \%$ 더 작게 나타났으며, 용접부 $\mathrm{EDS}$ 분석결과 잔여 마그 네슘 함량이 GMAW의 경우 37\%, GTAW의 경우 30\% 높은 값을 보였다.

본 연구 결과 $\mathrm{Al}-6 \mathrm{Mg}$ 의 용접부 인장강도는 $\mathrm{Al} 5083^{-}$ $\mathrm{O}$ 보다 용접부의 잔여 마그네슘 함량이 높았고, 더 작 은 평균결정립 크기를 갖는다. 이로 인해 $\mathrm{Al}-6 \mathrm{Mg}$ 의 용접부 인장강도는 $\mathrm{Al} 5083-\mathrm{O}$ 보다 향상되었다. 하지만 GMAW, GTAW 두 공정 모두 용접부에서 $\mathrm{Al}-6 \mathrm{Mg}$ 와 $\mathrm{Al} 5083-\mathrm{O}$ 의 경도가 비슷한 분포를 보였으며 이러한 원인을 규명하기 위해 연구를 진행 중이다.

\section{감사의 글}

본 연구는 산업통상자원부 글로벌주력산업품질 대응 
뿌리기술개발사업 “고품질 자동차 카울크로스의 글로벌 시장 진출을 위한 아크 용접 갭 보상 적응제어 기술 및 인공지능 기반 용접품질 통합관리 시스템 개발” 과제의 지원을 받아 수행되었습니다.

ORCID: Taehoon Kang: https://orcid.org/0000-0001-9469-6894

ORCID: Jiyoung Yu: https://orcid.org/0000-0002-0494-9497

ORCID: Young-Min Kim: https://orcid.org/0000-0003-3573-8753

ORCID: Insung Hwang: https://orcid.org/0000-0001-5572-8670

ORCID: Seung Hwan Lee: https://orcid.org/0000-0002-1509-3348

ORCID: Dong-Yoon Kim: https://orcid.org/0000-0002-9147-9971

\section{References}

1. J. C. Benedyk, Aluminum alloys for lightweight automotive structures, in Materials, Design and Manufacturing for Lightweight Vehicles, (City, 2010) 79-113. https://doi.org/10.1533/9781845697822.1.79

2. A. Musfirah and A. Jaharah, Magnesium and aluminum alloys in automotive industry, J. Appl. Sci. Res. 8(9) (2012) 4865-4875.

3. S. Jeoung and J. Ha, Lightweighting Technology Development and Trends in Automotive, Auto J. KSAE, 40(8) (2018) 30-34.

4. I. Chang, Y. Cho, H. Park, and D. So, Importance of Fundamental Manufacturing Technology in the Automotive Industry and the State of the Art Welding and Joining Technology, J. Weld. Join. 34(1) (2016) 21-25. https://doi.org/10.5781/JWJ.2016.34.1.21

5. R. Roth, J. Clark, and A. Kelkar, Automobile bodies, can aluminum be an economical alternative to steel?, JOM, 53(8) (2001) 28-32.

https://doi.org/10.1007/s11837-001-0131-7

6. Y. Jung, Aluminum Alloy Products for Automobile Use, KSAE, Korea, (18)(5) 38-52.

7. J. R. Davis, Aluminum and aluminum alloys, ASM international, (1993).

8. J. M. Mutua, Use of magnesium alloys in optimizing the weight of automobile, Current trends and opportunities, Sustainable Research and Innovation Proceedings, 3 (2011).

https://journals.jkuat.ac.ke/index.php/sri/acticle/view/49/52
9. W. Miller, L. Zhuang, J. Bottema, A. J. Wittebrood, P. De Smet, A. Haszler, and A. Vieregge, Recent development in aluminium alloys for the automotive industry, Mater. Sci. Eng. A, 280(1) (2000) 37-49. https://doi.org/10.1016/S0921-5093(99)00653-X

10. C. M. Allen, Laser Welding of Aluminum Alloys - Principles and Applications, TWI Report, 795/2004, (2004).

11. Korean Welding and Joining Society, Welding and Joining Handbook, Weldabilities of 7000 Aluminium Alloys (III), Korean Welding and Joining Society, Daejeon, Korea (2007) 320.

12. H. Kwon, C.-H. Park, I.-P. Hong, and N. Kang, Effects of High Current and Welding Wire Diameter on the Magnesium Vaporization and Mechanical Properties of Al5083-O Arc Welds, J. Korean Weld. Join. Soc. 31(6) (2013) 84-89.

13. W. Wen, Y. Zhao, and J. G. Morris, The effect of Mg precipitation on the mechanical properties of $5 \mathrm{xxx}$ aluminum alloys, Mater. Sci. Eng. A, 392(1-2) (2005) 136-144.

https://doi.org/10.1016/j.mesa.2004.09.059

14. B. Gungor, E. Kaluc, E. Taban, and S. Aydin, Mechanical and microstructural properties of robotic Cold Metal Transfer (CMT) welded 5083-H111 and 6082T651 aluminum alloys, Mater. Des. (1980-2015), 54 (2014) 207-211. https://doi.org/10.1016/j.matdes.2013.08.018

15. D. Kim, D. Kim, M. Kang, and Y. M. Kim, Effect of Aluminum Welding Wire Mg Content on the Machanical Properties of Al 5083 Alloy Weld Metal, Korean J. Met. Mater. 55(10) (2017) 716-723. https://doi.org/10.3365/KJMM.2017.55.10

16. S. I. Lee and Y. Cho, B. Hwang, Effect of Grain Size on the Tensile Properties of an Austenitic HighManganese Steel, Korean J. Mater. Res. (26)(6) (2016) 325-331. https://doi.org/10.3740/MRSK.2016.26.6.325

17. K. M. Youssef, R. O. Scattergood, K. L. Murty, and C. C. Koch, Nanocrystalline Al-Mg alloy with ultrahigh strength and good ductility, Scr. Mater. 54(2) (2006) 251-256. https://doi.org/10.1016/j.scriptamat.2005.09.028

18. G. Dini, R. Ueji, and A. Najafizadeh, Grain Size Dependence of the Flow Stress of TWIP Steel, Mater. Sci. Forum, 654-656 (2010) 294-297. https://doi.org/10.1016/j.matdes.2014.10.008 